Abant Tıp Dergisi

Araştırma Makalesi / Cilt 10 Sayı 1 Yıl 2021
Abant Medical Journal

Research Article / Volume 10 Issue 1 Year 2021

\title{
Obstrüktif Uyku Apne Sendromu Şiddetini Gösteren Kolay ve Pratik Yeni Belirteçler: Ortalama Trombosit Hacmi/Yüksek Dansiteli Lipoprotein ve Eritrosit Dağılım Hacmi/Yüksek Dansiteli Lipoprotein
}

\author{
New Hematological Indices as Simple and Practical Severity Markers of Obstructive Sleep Apnea \\ Syndrome: Mean Platelet Volume/High Density Lipoprotein and Red-Cell Diameter Width/High \\ Density Lipoprotein Ratio
}

Recep ALANLI ID, Murat Bülent KÜÇÜKAY ID, Kadir Serkan YALÇIN ID
Lokman Hekim University, Faculty of Medicine, Ankara Hospital, Department of Internal Diseases, Ankara, Turkey

Öz

GíRiş ve AMAÇ: Bu çalışmanın amacı, yeni birer belirteç olan; ortalama trombosit hacmi (MPV)/yüksek dansiteli lipoprotein (HDL) ve eritrosit dağılım hacmi (RDW)/HDL oranları ile obstrüktif uyku apne sendromu (OUAS) varlığı ve şiddeti arasındaki ilişkiyi değerlendirmektir.

YÖNTEM ve GEREÇLER: Ocak 2017 ile Mart 2020 arasında polisomnografi yapılan ve sonuçlarına eksiksiz ulaşılabilen 510 hasta ile çalışma yapılmıştır. Tiroid hormon düzeylerini ve uyku düzenini etkileyebilecek ilaç kullanan hastalar çalışma dışı tutulmuştur. OUAS olan ve OUAS olmayan hastaların; yaş, cinsiyet, nötrofil, lenfosit ve trombosit sayısı, ortalama eritrosit hacmi (MCV), MPV, RDW, HDL, monosit/HDL, MPV/HDL ve RDW/HDL oranları karşılaştırıldı. BULGULAR: OUAS şiddetiyle; yaş, HDL, RDW, MPV/HDL ve RDW/HDL oranı arasında anlamlı bir ilişki saptanmıştır. OUAS olanlarda kontrol grubuna göre (OUAS olmayan); yaş ve cinsiyet arasında anlamlı bir ilişki saptanmıştır.

TARTIŞMA ve SONUÇ: MPV/HDL ve RDW/HDL oranları, OUAS şiddetini göstermek için yeni birer belirteç olarak kullanılabilir.

Anahtar Kelimeler: Obstrüktif Uyku Apne Sendromu, Ortalama Trombosit Hacmi, Eritrosit Dağılım Hacmi, Yüksek Dansiteli Lipoprotein

\section{Abstract}

INTRODUCTION: The aim of this study is to analyze correlation between novel markers mean platelet volume (MPV)/high density lipoprotein (HDL) and erythrocyte diameter width (RDW)/HDL ratios, and existence and severity of OSAS.

METHODS: Patients who had polysomnography test between January 2017 to March 2020 were evaluated and 510 patients whose complete records could be obtained were enrolled. Participants who were using drugs affecting thyroid and sleep order were excluded. Participants were compared for age, gender, monocyte, neutrophil, lymphocyte and platelet counts, mean corpuscular volume (MCV), MPV, RDW, HDL, monocyte/HDL, MPV/HDL and RDW/HDL ratios in OSAS group and control group.

RESULTS: There was a significant correlation between severity of OSAS and age, HDL, RDW, MPV/HDL and RDW/HDL ratios. Compared to control group, there were significant differences in age $(p=0.005)$ and HDL $(p=0.001)$ in OSAS group.

DISCUSSION and CONCLUSION: MPV/HDL and RDW/HDL ratios may be used to predict severity of OSAS, as novel markers.

Keywords: Obstructive Sleep Apnea, MPV, RDW, HDL, MPV/HDL ratio, RDW/HDL ratio

\section{INTRODUCTION}

Obstructive sleep apnea syndrome (OSAS) will result in partial or total obstruction of upper respiratory tract in sleep. Snoring, daytime sleepiness, tiredness, diminished attention, increased appetite and weight gain, witnessed apnea, apathy and lethargy are usual symptoms of OSAS1. OSAS is characterized by recurring partial or total obstruction of upper airways. Obstruction of airway will result in paroxysmal hypoxia and hypoxia will disrupt sleep. Because of insufficient sleep in nighttime, suffering individual will experience daytime sleepiness2. Systemic inflammation has been reported to have a role in etiopathogenesis of OSAS. Balance among parasympathetic and sympathetic system disrupts and intrathoracic pressure changes 
according to. OSAS has interchanging hypoxia and re-oxygenation rounds, and hypoxia is the basis of tissue damage3.

Erythrocyte diameter width (RDW); will reflect heterogeneity of size of red cells. Increased value in RDW means increased size differences in erythrocytes. RDW will increase in existence of inflammation. RDW is reported to be increased in OSAS along with inflammation4.

Mean platelet volume (MPV) is an indicator showing thrombocyte size and functionality5. MPV is a sign of platelet activity, greater size of platelets will have greater thrombotic activity6. Compared to smaller sized platelets, greater sized platelets have more granules, will have greater affinity for collagen, produce more thromboxane A2 (increase thrombotic activity) and have more glycoprotein $1 b$ and $2 b / 3 a$ receptors7. In OSAS, platelets were reported to have increased thrombotic activity and aggregation8.

HDL has anti-platelet effect9. Also antiinflammatory and anti-oxidative effects of HDL were found to be protective in cardiovascular diseases10. HDL values were reported to be an independent predictor of RDW values11. Taking these into account, a ratio of RDW to HDL (RDW/HDL) was designed and the role of this ratio in showing severity of inflammation was inspected in OSAS.

MPV values of participants who have lower HDL values were reported to be higher, compared to participants having higher HDL values12. Since these two parameters were found related, a ratio of MPV to HDL (MPV/HDL) was designed and relation of MPV/HDL ratio to OSAS severity was analyzed in this reported study.

In this study it was aimed to analyze the relation of new inflammatory indicators; MPV/HDL and RDW/HDL ratios which are an easily available and relatively cheap tests with OSAS existence and OSAS severity.

\section{METHODS}

This is a single center, retrospective study conducted in a private hospital. Patients admitted to hospital between January 2017 to March 2020 with complaints of witnessed apnea, snoring, tiredness and daytime sleepiness who had polysomnography tests and were enrolled to study. Total of 899 patient records were inspected and 510 patients whose complete records could be obtained were enrolled. In order to eliminate negative effects of diseases and conditions on study parameters; participants having malignancies, acute infection, neuromuscular diseases and cerebrovascular disease histories were excluded since these might affect sleep quality. Participants who had transfusion history in the last 3 months, participants who were using lipid lowering drugs were also excluded, because those could affect study parameters.

Relation of OSAS severity to age, gender, monocyte, neutrophil, lymphocyte and platelet counts, mean erythrocyte volume (MCV), MPV, RDW, HDL, monocyte/HDL ratio and novel indicators MPV/HDL and RDW/HDL ratios were analyzed. Participants were grouped into two groups according to existence of OSAS. Participants having OSAS were divided into three groups according to apnea-hypopnea index (AHI). Participants who had similar complaints and whose polysomnography tests turned out normal were constituted into control group. The patients in OSAS and control groups were compared for age, gender, monocyte, neutrophil, lymphocyte and platelet counts, MCV, MPV, RDW, HDL, monocyte/HDL, MPV/HDL and RDW/HDL ratios. This study was approved by local ethics committee (App.No: 2020/017) and conducted in concordance with Helsinki declaration and good clinical practice guidelines.

\section{Polysomnography}

All participants who had polysomnography test 
with Embla N7000 (Natus Neurology, Embla Systems, Ontario, Canada) were monitored by video records supervised by an experienced technician, in a room with single bed. Patients' respiratory patterns, leg electromyography (EMG), electrocardiography (ECG), nasal airflow, thoracic and abdominal respiratory movements and blood oxygenation levels with a pulse oxymeter were recorded for all patients. Criteria of American Academy of Sleep Medicine (AASM) in 2012 were used in scoring of polysomnography records. Apnea and hypopnea frequency during sleep was inspected and apnea-hypopnea index were calculated. Apnea was defined as; $90 \%$ decrease in airflow through nose or mouth lasting at least 10 seconds. Hypopnea was defined as; $30 \%$ decrease in airflow and a decrease in blood oxygen saturation more than $3 \%$ lasting at least 10 seconds. AHI was calculated with the sum of apnea and hypopnea. AHI value less than 5 were accepted to be normal and not having OSAS. Values between 5 to 15 were accepted to have mild OSAS, 15 to 30 were accepted as moderate OSAS and values greater than 30 were accepted as having severe OSAS.

Blood samples were taken after polysomnography test before breakfast. Whole blood count test were analyzed by Sysmex XN1000 (USA). Lipid values were analyzed by chemiluminescence method in Roche Hitachi Cobas 501 (Switzerland).

\section{Statistical Analysis}

All data were analyzed in SPSS version 25.0 (SPSS Inc., Chicago, IL, USA). All variables were inspected by Kolmogorov-Smirnov test and distribution were normal. Data were reported as mean \pm standard deviation. One way Anova test was used to analyze difference between groups. Results having $p$ value $<0.05$ was accepted as significant statistically.

\section{RESULTS}

Compared to control group, there were significant differences in age $(p=0.005)$ and HDL $(p=0.001)$ in OSAS group. However, there were no significant correlation between OSAS and gender, monocyte, neutrophil, lymphocyte, platelet count, MCV, MPV, RDW, monocyte/HDL, RDW/HDL and MPV/HDL ratios. Clinical and laboratory characteristics of the patients with OSAS and non-OSAS group are shown in table 1.

The polysomnography results of 510 patients showed that $26(\% 5)$ participants did not have OSAS and 484 (\%95) had OSAS; 76 (\%15) patients had mild, 137 (\%27) patients had moderate and 271 (\%53) patients had severe OSAS. Participants were 17 to 93 years old. Of 510 patients enrolled to the study; 361 (\%71) were male and 149 (\%29) were female. Mean age of participants were $50.45 \pm 11.94$ years. Male participants' mean age were $48.83 \pm 11.86$. Female participants' mean age were $54.40 \pm 11.86$.

The comparison of the control group with mild, moderate and severe OSAS groups showed significant differences for age, HDL, RDW, RDW/HDL and MPV/HDL ratios. However, there were no significant correlation between OSAS severity and gender, monocyte, neutrophil, lymphocyte and platelet count, MCV, MPV, and monocyte/HDL ratio (Table 2).

There was significant differences between the control group and severe OSAS subgroup and between mild and severe OSAS subgroup for age. There was significant differences between the control group and moderate OSAS subgroup and severe OSAS subgroup, and between mild and severe OSAS subgroups for HDL. There was significant differences between mild and severe OSAS subgroups, and between moderate and severe OSAS subgroups for RDW. There was a significant difference between mild and severe OSAS subgroups for RDW/HDL ratio. There was a significant difference between mild and severe OSAS subgroups for MPV/HDL ratio (Table 3 ). 
Table 1. The characteristics of OSAS* and control group

\begin{tabular}{|c|c|c|c|}
\hline & OSAS group & Control group & p value \\
\hline Age (years) & $50.80 \pm 11.87$ & $44,04 \pm 11.73$ & 0.005 \\
\hline Gender (female/male)(\%) & $71 / 29$ & $69 / 31$ & 0.850 \\
\hline $\mathrm{HDL}^{\dagger}(\mathrm{mmol} / \mathrm{L})$ & $1.07 \pm 0.23$ & $1.29 \pm 0.47$ & 0.001 \\
\hline Monocyte $\left(\times 10^{6} / \mathrm{L}\right)$ & $0.67 \pm 0.43$ & $0.60 \pm 0.21$ & 0.410 \\
\hline Neutrophil $\left(\times 10^{6} / \mathrm{L}\right.$ & $5.01 \pm 2.00$ & $5.3 \pm 2.00$ & 0.470 \\
\hline Lymphocyte $\left(\times 10^{6} / \mathrm{L}\right.$ & $2.56 \pm 0.80$ & $2.43 \pm 0.80$ & 0.460 \\
\hline Platelet Count $\left(\times 10^{9} / \mathrm{L}\right.$ & $266 \pm 66$ & $262 \pm 56$ & 0.760 \\
\hline $\mathrm{MCV}^{*}(\mathrm{fL})$ & $83.5 \pm 5.0$ & $82.9 \pm 5.0$ & 0.600 \\
\hline $\mathrm{MPV}^{\S}(\mathrm{fL})$ & $9.91 \pm 1.00$ & $10.1 \pm 1.00$ & 0.220 \\
\hline RDW" $(\%)$ & $13.5 \pm 1.8$ & $13.4 \pm 1.4$ & 0.770 \\
\hline Monocyte /HDL & $0.17 \pm 0.012$ & $0.13 \pm 0.007$ & 0.240 \\
\hline RDW/HDL & $0.34 \pm 0.09$ & $0.3 \pm 0.09$ & 0.090 \\
\hline MPV/HDL & $0.25 \pm 0.07$ & $0.23 \pm 0.05$ & 0.270 \\
\hline
\end{tabular}

* Obstructive Sleep apnea syndrome

† High density lipoprotein $\quad \ddagger$ Mean erythrocyte volume

$\S$ Mean platelet volume II Erythrocyte diameter width

Table 2. Comparison of control and OSAS* subgroups for characteristic features and laboratory parameters

\begin{tabular}{lccccc}
\hline & Controls & Mild OSAS & $\begin{array}{c}\text { Moderate } \\
\text { OSAS }\end{array}$ & $\begin{array}{c}\text { Severe } \\
\text { OSAS }\end{array}$ & P value \\
\hline Age $(\mathrm{y})$ & $44.04 \pm 11.73$ & $46.4 \pm 11$ & $49.6 \pm 12$ & $52.62 \pm 11$ & $<\mathbf{0 . 0 0 1}$ \\
Gender $($ female/male) $(\%)$ & $69 / 31$ & $66 / 34$ & $74 / 26$ & $71 / 29$ & 0.680 \\
$\mathrm{HDL}^{\dagger}(\mathrm{mmol} / \mathrm{L})$ & $1.29 \pm 0.47$ & $1.15 \pm 0.23$ & $1.07 \pm 0.23$ & $1.05 \pm 0.21$ & $\mathbf{0 . 0 0 1}$ \\
${\text { Monocyte }\left(\times 10^{6} / \mathrm{L}\right)}$ & $0.6 \pm 0.2$ & $0.59 \pm 0.1$ & $0.69 \pm 0.7$ & $0.67 \pm 0.2$ & 0.270 \\
Neutrophil $\left(\times 10^{6} / \mathrm{L}\right.$ & $5.3 \pm 2.1$ & $4.6 \pm 1.5$ & $4.8 \pm 2.0$ & $5.2 \pm 2.0$ & 0.090 \\
Lymphocyte $\left(\times 10^{6} / \mathrm{L}\right.$ & $2.4 \pm 0.8$ & $2.6 \pm 0.8$ & $2.5 \pm 0.7$ & $2.5 \pm 0.8$ & 0.800 \\
Platelet Count $\left(\times 10^{9} / \mathrm{L}\right.$ & $262 \pm 56$ & $262 \pm 67$ & $266 \pm 63$ & $266 \pm 68$ & 0.990 \\
MCV $^{\ddagger}(\mathrm{fL})$ & $82.9 \pm 5.8$ & $83.2 \pm 5.2$ & $84 \pm 4.9$ & $83.4 \pm 6.0$ & 0.700 \\
$\mathrm{MPV}^{\S}(\mathrm{fL})$ & $10.1 \pm 1$ & $9.7 \pm 0.8$ & $9.8 \pm 1.1$ & $9.9 \pm 1.0$ & 0.220 \\
$\mathrm{RDW}^{\|}(\%)$ & $13.4 \pm 1.4$ & $13.1 \pm 1.4$ & $13 \pm 1.0$ & $13.8 \pm 2.0$ & $<\mathbf{0 . 0 0 1}$ \\
Monocyte $/ \mathrm{HDL}$ & $0.013 \pm 0.002$ & $0.013 \pm 0.001$ & $0.017 \pm 0.02$ & $0.07 \pm 0.001$ & 0.160 \\
$\mathrm{RDW} / \mathrm{HDL}$ & $0.3 \pm 0.09$ & $0.31 \pm 0.07$ & $0.33 \pm 0.07$ & $0.35 \pm 0.10$ & $\mathbf{0 . 0 0 2}$ \\
MPV/HDL & $0.23 \pm 0.07$ & $0.22 \pm 0.05$ & $0.25 \pm 0.06$ & $0.25 \pm 0.05$ & $\mathbf{0 . 0 2 8}$ \\
\hline
\end{tabular}

* Obstructive Sleep apnea syndrome

† High density lipoprotein

₹ Mean erythrocyte volume

$\S$ Mean platelet volume

II Erythrocyte diameter width 
Table 3. Statistical comparison of OSAS* subgroups and the control group

\begin{tabular}{|c|c|c|c|c|c|c|}
\hline & $\begin{array}{c}\text { Normal- } \\
\text { mild OSAS } \\
\text { p value }\end{array}$ & $\begin{array}{c}\text { Normal- } \\
\text { moderate } \\
\text { OSAS } \\
\text { p value }\end{array}$ & $\begin{array}{c}\text { Normal- } \\
\text { severe } \\
\text { OSAS } \\
\text { p value }\end{array}$ & $\begin{array}{c}\text { Mild- } \\
\text { moderate } \\
\text { OSAS } \\
\text { p value }\end{array}$ & $\begin{array}{l}\text { Mild- } \\
\text { severe } \\
\text { OSAS } \\
\text { p value }\end{array}$ & $\begin{array}{c}\text { Modere- } \\
\text { severe OSAS } \\
\text { p value }\end{array}$ \\
\hline Age & 0.800 & 0.110 & 0.002 & 0.210 & $<0.001$ & 0.070 \\
\hline Gender & 0.980 & 0.960 & 0.990 & 0.610 & 0.820 & 0.930 \\
\hline $\mathrm{HDL}^{\dagger}$ & 0.240 & 0.010 & 0.002 & 0.290 & 0.050 & 0.870 \\
\hline Monocyte & 0,998 & 0.710 & 0.800 & 0.310 & 0.400 & 0.970 \\
\hline Neutrophil & 0.460 & 0.710 & 0.990 & 0.890 & 0.140 & 0.340 \\
\hline Lymphocyte & 0.790 & 0.950 & 0.880 & 0.900 & 0.960 & 0.980 \\
\hline Platelet Count & 0.990 & 0.980 & 0.980 & 0.991 & 0.989 & 0.991 \\
\hline MCV: & 0.990 & 0.830 & 0.970 & 0.780 & 0.990 & 0.800 \\
\hline $\mathrm{MPV}^{\S}$ & 0.380 & 0.450 & 0.810 & 0.990 & 0.500 & 0.560 \\
\hline $\mathrm{RDW} \|$ & 0.910 & 0.850 & 0.670 & 0.990 & 0.020 & 0.001 \\
\hline Monocyte /HDL & 0.990 & 0.570 & 0.550 & 0.300 & 0.230 & 0.991 \\
\hline RDW/HDL & 0.990 & 0.650 & 0.110 & 0.510 & 0.008 & 0.120 \\
\hline MPV/HDL & 0.990 & 0.750 & 0.480 & 0.200 & 0.020 & 0.840 \\
\hline
\end{tabular}

\section{DISCUSSION}

The present study mainly examined the relationship between MPV/HDL and RDW/HDL ratio and OSAS severity. To the best of our knowledge, this is the first study to investigate this association. The results showed that these novel indicators were increased along with the severity of OSAS. When compared to other inflammatory markers that are costly and require special laboratory resources, such as interleukin6 (IL-6), interleukin-8 (IL-8), inter cellular adhesion molecule, vascular cell adhesion molecule13, selectins and tumor necrosis factor alfa (TNF- $\alpha$ ), these novel indicators can be easily and commonly used with lower costs.

Existence of systematic inflammation in OSAS is already known3. When severity of inflammation increases, severity of OSAS also increases3. In OSAS; intermittent hypoxia is more dangerous than continuous hypoxia, because re- oxygenation will generate reactive oxygen species14. Intermittent hypoxia is reported to cause systemic inflammation15. Continuous positive airway pressure (CPAP) treatment is being used in OSAS and this treatment will result in a decrease in inflammatory indicators 16.

In a study with general population, it has been reported that increase in RDW values were associated to lower high density lipoprotein (HDL) and increased inflammation was reported as the cause17. People having low HDL levels will have higher oxidative stress and inflammation. Inflammation will cause an increase in MPV levels18. There was an inverse relation between HDL and RDW in coronary artery disease11. Low HDL levels may cause inflammation and this will result in higher MPV levels19. HDL also increases nitric oxide (NO) synthesis and release from endothelial cells and affects thrombocyte functions. NO increase megakaryocyte 
production20. So increases in RDW and decrease in HDL values were expected in more severe OSAS groups and significant statistical difference was found between HDL and RDW/HDL ratio and OSAS severity in this reported study as expected. Anti-inflammatory and anti-oxidative effects of HDL may improve severity of OSAS.

Inflammatory indicators were found to be useful in predicting sleep time hypoxia and complications in OSAS21. AHI, MPV and RDW were found to be related with acute or chronic hypoxia in OSAS21. In a study with rats, chronic intermittent hypoxia was found to be increasing thrombocyte activity and thrombosis22. Desaturation of oxygen will increase thrombocyte surface adhesion molecules, glycoprotein receptor activity, thrombocyte and monocyte aggregation23. Chronic inflammation and oxidative stress were found to be related to increase in RDW values24. Thus, MPV and RDW values are related with OSAS severity. In this reported study, RDW level was significantly higher in moderate and severe OSAS patients. There was no relationship ship between MPV and OSAS severity but there was a significant difference between mild and severe OSAS subgroups for MPV/HDL ratio. MPV/HDL ratio can be used as an inflammatory indicator.

Prevalence of OSAS increases with age between age 18 and 45, and draws plateau between ages 55 and 6524. Also prevalence of OSAS in men was found to be two times more than women 25 . Similarly, in this reported study $71 \%$ of participants who had OSAS were men and severity of OSAS was found to be increasing with age. In a study with 2006 men and 339 women participants reported by Huang et al. OSAS severity was found to be distinctively frequent in men compared to women26. But reported study did not reveal any association between severity of OSAS and gender.

There are some limitations in this study. Study was retrospectively planned and only participants whose complete records could be retrieved were enrolled to study. Only $\mathrm{AHI}$ data was used since other data gathered (oxygen desaturation indexes and cumulative time percentage with oxygen saturation below $90 \%$ from nocturnal oximetry) in polysomnography could not be reached. Also control group constituted from participants whose polysomnography were normal and number in this group was comparatively low. Another point to be mentioned may be the changes in these inflammatory markers in follow up of patients who had surgical intervention or effect of CPAP treatment in severe OSAS group. Since the study was retrospective, changes in these novel inflammatory markers were not followed up and effects of treatments could not be inspected.

In conclusion; MPV/HDL and RDW/HDL ratios can be used in determining severity of OSAS. More studies conducted with MPV/HDL and RDW/HDL ratios may be useful for evaluating usability of these novel indicators in other inflammatory conditions.

\section{Acknowledgments}

Authors wish to thank sleep laboratory personnel for their kind help in gathering patient information, Mr. Fatih Acikgoz for his help in statistical analysis and Dr. Dogan ATAN for evaluation of polysomnography results.

Author Contribution: Concept - R.A.; Design R.A, M.B.K., K.S.Y; Supervision - R.A, M.B.K., K.S.Y; Resources and Materials- R.A, M.B.K., K.S.Y; Data Collection and/or Processing R.A, M.B.K., K.S.Y; Analysis and Interpretation - R.A, M.B.K., K.S.Y; Literature Search - R.A, M.B.K.; Writing Manuscript - R.A., M.B.K.; Critical Review - R.A, M.B.K., K.S.Y;

Informed Consent: Written consent was obtained from the participants.

Conflict of Interest: Authors declared no conflict of interest. 
Financial Disclosure: Authors declared no financial support.

\section{REFERENCES}

1. Attal P, Chanson P. (2010). Endocrine Aspects of Obstructive Sleep Apnea. The Journal of Clinical Endocrinology \& Metabolism, 95(2), 483-495.

2. Thorpy M. (2017). International Classification of Sleep Disorders. Sleep Disorders Medicine, 475-484.

3. Xie JY1, Liu WX, Ji L, Chen Z, Gao JM, Chen W, Chen GF, Zhu Q. Relationship between inflammatory factors and arrhythmia and heart rate variability in OSAS patients. Eur Rev Med Pharmacol Sci. 2020 Feb;24(4):20372053.

4. Ozsu S, Abul Y, Gulsoy A, Bulbul Y, Yaman S, Ozlu T. (2012). Red Cell Distribution Width in Patients with Obstructive Sleep Apnea Syndrome. Lung, 190(3), 319326.

5. Davi G, Patrono C. (2007). Platelet Activation and Atherothrombosis. New England Journal of Medicine, 357(24), 2482-2494.

6. Park Y, Schoene N, Harris W. (2002). Mean platelet volume as an indicator of platelet activation: methodological issues. Platelets, 13(5-6), 301-306.

7. Giles H, Smith RE, Martin JF. (1994). Platelet glycoprotein IIb-IIla and size are increased in acute myocardial infarction. European Journal of Clinical Investigation, 24(1), 69-72.

8. Nena $E$, Papanas $N$, Steiropoulos $P$, Zikidou $P$, Zarogoulidis P, Pita E, Constantinidis TC, Maltezos E, Mikhailidis DP, Bouros D. (2011). Mean Platelet Volume and Platelet Distribution Width in non-diabetic subjects with Obstructive Sleep Apnoea Syndrome: New indices of severity? Platelets, 23(6), 447-454.

9. Vazzana N, Ganci A, Cefalu AB, Lattanzio S, Noto D, Santoro N, Saggini R, Puccetti L, Averna M, Davi G. (2013). Enhanced Lipid Peroxidation and Platelet Activation as Potential Contributors to Increased Cardiovascular Risk in the Low-HDL Phenotype. Journal of the American Heart Association, 2(2).

10. Podrez EA. (2010). Anti-oxidant properties of highdensity lipoprotein and atherosclerosis. Clinical and Experimental Pharmacology and Physiology, 37(7), 719-725.

11. Avci E, Kiris T, Demirtas AO, Kadi H. (2018). Relationship between high-density lipoprotein cholesterol and the red cell distribution width in patients with coronary artery disease. Lipids in Health and Disease, 17(1).

12. Varol E, Aksoy F, Bas HA, Ari H, Ozaydin M. (2013). Mean Platelet Volume is Elevated in Patients With Low High-Density Lipoprotein Cholesterol. Angiology, 65(8), 733-736.

13. Ursavas $A$, Karadag $M$, Rodoplu E, Yilmaztepe A, Oral $\mathrm{HB}$, Gozu RO. Circulating ICAM-1 and VCAM-1 Levels in
Patients with Obstructive Sleep Apnea Syndrome. Respiration. 2007;74(5):525-32.

14. Planellas M, Cuenca R, Tabar MD, Bertolani C, Poncet C, Closa JM, Lorente J, Ceron JJ, Pastor J. (2015). Clinical assessment and C-reactive protein (CRP), haptoglobin $(\mathrm{Hp})$, and cardiac troponin I (cTnl) values of brachycephalic dogs with upper airway obstruction before and after surgery. Canadian Journal of Veterinary Research $=$ Revue Canadienne De Recherche Veterinaire, 79(1), 58-63.

15. Nizam N, Basoglu OK, Tasbakan MS, Lappin DF, Buduneli N. (2015). Is there an association between obstructive sleep apnea syndrome and periodontal inflammation? Clinical Oral Investigations, 20(4), 659668.

16. Yokoe T, Minoguchi K, Matsuo H, Oda, N, Minoguchi H, Yoshino G, Hirano T, Adachi M. (2003). Elevated Levels of C-Reactive Protein and Interleukin-6 in Patients With Obstructive Sleep Apnea Syndrome Are Decreased by Nasal Continuous Positive Airway Pressure. Circulation, 107(8), 1129-1134.

17. Lippi G, Sanchis-Gomar F, Danese E, Montagnana M. (2013). Association of red blood cell distribution width with plasma lipids in a general population of unselected outpatients. Kardiologia Polska, 931-936.

18. Gasparyan A, Ayvazyan L, Mikhailidis D, Kitas G. (2011). Mean Platelet Volume: A Link Between Thrombosis and Inflammation? Current Pharmaceutical Design, 17(1), 47-58.

19. Varol E, Aksoy F, Ozaydin M, Erdogan D, Dogan A. (2014). Association between neutrophil-lymphocyte ratio and mitral annular calcification. Blood Coagulation \& Fibrinolysis, 25(6), 557-560.

20. Battinelli E, Willoughby SR, Foxall T, Valeri CR, Loscalzo J. (2001). Induction of platelet formation from megakaryocytoid cells by nitric oxide. Proceedings of the National Academy of Sciences, 98(25), 1445814463.

21. Wu, M., Zhou, L., Zhu, D., Lai, T., Chen, Z., \& Shen, H. (2018). Hematological indices as simple, inexpensive and practical severity markers of obstructive sleep apnea syndrome: a meta-analysis. Journal of Thoracic Disease, 10(12), 6509-6521.

22. Dunleavy M, Dooley M, Cox D, Bradford A. (2005). Chronic intermittent asphyxia increases platelet reactivity in rats. Experimental Physiology, 90(3), 411416.

23. Rahangdale $S$, Yeh SY, Novack V, Stevenson $K$, Barnard MR, Furman MI, Frelinger AL, Michelson AD, Malhotra A. (2011). The Influence of Intermittent Hypoxemia on Platelet Activation in Obese Patients with Obstructive Sleep Apnea. Journal of Clinical Sleep Medicine, 07(02), 172-178.

24. Ferrucci L, Guralnik JM, Woodman RC, Bandinelli $S$, Lauretani F, Corsi AM, Chaves PA, Ershler WB, Longo 
Alanlı R. ve Ark.

DL. (2005). Proinflammatory state and circulating erythropoietin in persons with and without anemia. The American Journal of Medicine, 118(11), 1288.e111288.e19.

25. Jennum P, Riha RL. (2009). Epidemiology of sleep apnoea/hypopnoea syndrome and sleep-disordered breathing. European Respiratory Journal, 33(4), 907914.

26. Huang KT, Chin $\mathrm{CH}$, Tseng $\mathrm{CC}$, Chang $\mathrm{HC}$, Chen YC, Wang CC, Lin MC, Lin HC, Su MC. (2014). The Influence of Obesity on Different Genders in Patients with Obstructive Sleep Apnea. The Scientific World Journal, 2014, 1-8. 